\title{
Brown Algae and Basalt Meal in Maintaining the Activity of Arylsulfatase of Soil Polluted with Cadmium
}

\author{
Magdalena Zaborowska • Jan Kucharski • \\ Jadwiga Wyszkowska
}

Received: 21 March 2017 / Accepted: 23 June 2017 / Published online: 7 July 2017

(C) The Author(s) 2017. This article is an open access publication

\begin{abstract}
This study analysed the effectiveness of innovative (basalt meal, brown algae extract) and conventional (barley straw) substances which hypothetically alleviate the inhibiting effect of $\mathrm{Cd}^{2+}$ on biochemical properties of soil, with particular regard to the activity of arylsulfatase. An analysis of their potential was carried out based on the activity of arylsulfatase and the number of Pseudomonas sp. determined on the 25th and 50th days of the study. $\mathrm{Cd}^{2+}$ was applied in the following doses: $0,4,40,80,120,160,200 \mathrm{mg} \mathrm{Cd}^{2+} \mathrm{kg}^{-1}$ of DM soil, in the form of $\mathrm{CdCl}_{2} \cdot 2.5 \mathrm{H}_{2} \mathrm{O}$. A complex formulation of the issue was obtained from the presentation of biochemical properties using the RS (resistance of soil) index. Cadmium caused permanent adverse effects in the soil environment, inhibiting the activity of arylsulfatase and the yield of spring barley. The consequences of stress connected with increasing $\mathrm{Cd}^{2+}$ pollution were intensified by an elongation of the accumulation time of the tested metal in the soil. Chances for regeneration of the soil may be sought, most of all, with the application of straw and, to a lesser degree, with basalt meal. Brown algae did not meet the expectations for its potential. An increase in the studied parameters also resulted from sowing the soil with spring barley.
\end{abstract}

Keywords Cadmium $\cdot$ Arylsulfatase $\cdot$ Pseudomonas $\mathrm{sp} . \cdot$ Algae $\cdot$ Basalt meal $\cdot$ Soil

M. Zaborowska · J. Kucharski · J. Wyszkowska $(\bowtie)$

Department of Microbiology, University of Warmia and Mazury in Olsztyn, Plac Łódzki 3, 10-727 Olsztyn, Poland

e-mail: jadwiga.wyszkowska@uwm.edu.pl

\section{Introduction}

Rapid industrialisation and urbanisation and the resulting high global demand for $\mathrm{Cd}^{2+}$, have raised concerns about the effects of environmental pollution with cadmium and other heavy metals. Long-term exposure to cadmium is associated with kidney damage, bone mineral loss, increased risk of bone fractures and reduced lung function (ASTDR 2012). Phosphatic fertilisers, sediments (Smith 2009), electroplating, sites for the disposal of waste from industrial processes (Khan et al. 2008) and the manufacture of plastics and paint pigments (Rao et al. 2010) are sources of $\mathrm{Cd}^{2+}$ in the soil. It is estimated that over 8 million $\mathrm{mg}$ of phosphate fertilizer were used in the USA in 2010 (ASTDR 2012). The EPA ceiling limit for the cadmium content of sludge applied to land is $85 \mathrm{mg} \mathrm{kg}^{-1}$ in sewage sludge and the maximum annual cadmium loading is $1.9 \mathrm{~kg}^{-1} \mathrm{ha}^{-1}$ year ${ }^{-1}$ (EPA 2011). Its availability in the soil environment is affected by various factors, including soil $\mathrm{pH}$ (Houben et al. 2013), content of dissolved organic carbon (Longhua et al. 2012) and plant species (Mahmood et al. 2014). Nevertheless, the accumulation of $\mathrm{Cd}^{2+}$ in the soil, disturbing its homeostasis, is the most serious problem. Symptoms of the adverse influence of $\mathrm{Cd}^{2+}$ on the soil ecosystem may also be found in its biochemical properties (Kucharski et al. 2011; Wyszkowska et al. 2013), which correspond directly with soil fertility and plant yield (Oropeza-Garcia et al. 2014). Some of these symptoms include inhibition of chlorophyll biosynthesis, the activity of $\delta$ aminolaevulin acid synthase and protochlorophyllide reductase (Macfarlane and Burchett 2001). This results in 
oxidation stress, leading to an increased peroxidation of lipids and the production of a reactive form of oxygenhydrogen peroxide - in both roots and leaves (Hao et al. 2006). Exposure to high $\mathrm{Cd}^{2+}$ doses, exceeding the tolerance of plants, is directly connected with an increase in ethylene level, and thus the activity of ACC (1-aminocyclopropane-1-carboxylic acid) which is responsible for its synthesis (Maksymiec et al. 2007). One method for the decrease of $\mathrm{Cd}^{2+}$ availability to plants consists in increasing the amount of phosphorus (Mohamed et al. 2012). Data based on in vitro examination of the genotoxic effects of cadmium in microorganisms, suggests that this xenobiotic has the potential to induce DNA damage, micronuclei, chromosomal aberrations and genetic mutations (ASTDR 2012).

Among the numerous reliable parameters for evaluation of the soil condition, enzymatic activity is among those most often used (Jezierska-Tyś and Frąc 2006). Arylsulfatase - apart from dehydrogenases, urease and phosphatases - is most frequently used as an indicator for the pollution of soils with heavy metals and pesticides (Gil-Sotres et al. 2005; Zaborowska et al. 2016). There is also a growing need for the quantification of the activity of enzymes, both intra- and extracellular, to which arylsulfatase belongs, in order to create an opportunity for a reliable analysis of the microorganism potential in soil transformations (Zwikel et al. 2007). Arylsulfatase (sulfohydrolase, EC 3.1.6.1) is an important enzyme because of the common occurrence of sulphur in the soil and making it available to plants in an oxidation process. This enzyme hydrolyses aromatic sulphate (VI) esters (R-O- $\mathrm{SO}_{3}{ }^{2-}$ ) to phenols (R-OH) and inorganic sulphates (VI) $\left(\mathrm{SO}_{4}{ }^{2-}\right)$ (Elsgaard and Vinther 2004). In most soils, $95 \%$ of the sulphur content is represented by sulfonates and sulphate esters. According to Kahnert and Kertesz (2000), Pseudomonas putida has regulatory proteins (AsfR) which are necessary for the desulphonation of aromatic and aliphatic sulfonates. Directed evolution, generated by an intention to improve the enzymatic properties of soils, contributed to the isolation of an H260L arylsulfatase from a Pseudoalteromonas carrageenovora mutant, which is an enzyme much more resistant to the variable properties of the solum (Zhu et al. 2017). Arylsulfatase activity is closely correlated with the microbial activity (Vong et al. 2010). Kertesz et al. (1993) demonstrated that the reduction in the source of sulphates resulted in the specific expression of proteins in Pseudomonas sp., contributing to an increase in arylsulfatase activity by up to 140 times. The proteins induced under these conditions were involved in sulphur metabolism. They are referred to as sulphate starvation-induced (SSI) proteins and have been divided into three groups based on the functions they serve in response to sulphur deficit. This is why the enzyme is frequently considered to be the SSI protein of groups I and III, synthesized by microorganisms (Byun et al. 2004), mainly characterized by Protobacteria (Berteau et al. 2006) and fungi Eupenicillium sp. or Trichoderma sp. (SlezackDeschaumes et al. 2012). The discovery of the regulation of arylsulfatase activity at the transcriptional level allows one to conclude that arylsulfatase synthesis may also be induced to release sulphates from alternative sulphur sources such as sulphuric acid esters (Piutti et al. 2015).

The effects of the application of mitigating substances depend on a multiplicity of transformations occurring in the soil. Eventually, fertilisation may neutralise the consequences of the pressure that the soil polluted with $\mathrm{Cd}^{2+}$ has been subjected to. The use of algae for this purpose may prove a good solution, in spite of the fact that various preferences of algae towards the individual metals $(\mathrm{Cu}>\mathrm{Cd}>\mathrm{Zn}$ ) have been found (Yoshida et al. 2006). However, their adsorptive properties connected with the use of a proper biomass of bacteria make them attractive biosorbents (Munoz et al. 2006), in the presence of organic compounds (Abinandan and Shanthakumar 2015). However, it should be noted that the regenerative potential of algae may be highly strainspecific. Monteiro et al. (2010) noted a 25\% difference in the biosorption of $\mathrm{Cd}^{2+}$ by two strains of Desmodesmus pleiomorphus. Straw, as an unrivalled source of carbon, is also a good material for fertilisation of the soil environment (Badía et al. 2013). Basalt meal, with the co-participation of an additional carbon source, is also able to increase the plant yield (Anda et al. 2013). According to Nunes et al. (2014), basalt from mining waste can be used as a fertiliser, thus reducing the scope of the disposal of such waste while contributing to sustainable development.

In order to reliably evaluate the chances for maintaining or restoring the equilibrium in the soil subjected to strong $\mathrm{Cd}^{2+}$ pressure, changes in its stability over time were traced, by determination of the indicators of the resistance of soil (RS) to arylsulfatase. The analysed parameter was also presented as a rhizosphere effect (R:S), taking into account the influence of spring barley. Moreover, the evaluation of the influence of $\mathrm{Cd}^{2+}$ on the 
yield of the cultivated plant was carried out. However, the primary goal was to compare the efficiency of the alleviation of adverse effects of $\mathrm{Cd}^{2+}$ accumulation in the soil by basalt meal and brown algae extract in relation to the conventional method of fertilisation with barley straw.

\section{Material and Methods}

\subsection{Soil and Experimental Procedure}

Soil used in the vegetation experiment originated from the Didactic and Research Centre in Tomaszkowo situated in NE Poland (53.71610 N, 20.41670 E). The zone for the research has a surface area-including protective belts - of approximately 4.5 ha. The soil material was sampled from the topsoil of typical brown earths (Eutric Cambisol). According to the graining classification of the United States Department of Agriculture, it is a soil with a granulometric composition of loamy sand. The soil physicochemical characterisation has been performed (Table 1). The following soil properties were defined: reaction $(\mathrm{pH})$ by potentiometric in an aqueous solution of $\mathrm{KCl}$ of the concentration of $1 \mathrm{~mol} \mathrm{dm}^{3}$ (ISO 10390, 2005); hydrolytic acidity (HAC) and exchangeable base cations (EBC) - by the Kappen method (Klute 1996), content of organic carbon (Corg) - by the Tiurin method (Nelson and Sommers 1996). Based on the $\mathrm{HAC}$ and EBC values, the cation exchange capacity (CEC) and base saturation (BS) of the soil were

Table 1 Some physicochemical properties of soil used in the experiment

\begin{tabular}{llc}
\hline Properties & Unit & Value \\
\hline Granulometric composition & $2.00 \geq d \geq 0.05 \mathrm{~mm}$ & 75 \\
$\quad$ of soil & $0.05 \geq d>0.002 \mathrm{~mm}$ & 20 \\
(percentage of fraction $(d))$ & $d \leq 0.002 \mathrm{~mm}$ & 5 \\
$\mathrm{pH}_{\mathrm{KCl}}$ & & 5.8 \\
$\mathrm{HAC}$ & $\mathrm{mM}(+) \mathrm{kg}^{-1} \mathrm{DM}$ of soil & 14.75 \\
$\mathrm{EBC}$ & & 48.67 \\
$\mathrm{CEC}$ & & 63.42 \\
$\mathrm{BS}$ & $(\%)$ & 76.75 \\
$\mathrm{Corg}$ & $\mathrm{g} \mathrm{kg}^{-1} \mathrm{DM}$ of soil & 6.4 \\
\hline
\end{tabular}

HAC hydrolytic acidity, $E B C$ sum of exchangeable cations, $C E C$ cation exchange capacity, $B S$ base saturation, $p H_{K C l}$ soil reaction computed. The following equations were applied: $\mathrm{CEC}=\mathrm{EBC}+\mathrm{HAC} ; \mathrm{BS}=(\mathrm{EBC} / \mathrm{CEC}) \cdot 100$.

The second stage of the studies was realized in the plant house of the University of Warmia and Mazury in Olsztyn (NE Poland), based on a pot experiment carried out in five replications.

The influence of the following variables was evaluated: (1) degree of pollution of the soil with cadmium in mg Cd${ }^{2+} \mathrm{kg}^{-1}$ DM of soil: 0, 4, 40, 80, 120, 160, 200, (2) addition of fertilizing substances: basalt meal, Labimar 10S - algae extract, finely ground straw of spring barley, (3) soil use: unsown treatments and treatments sown with spring barley (Hordeum vulgare L.) and (4) duration of the studies: 25, 50 days.

Before commencing the experiment, the soil material was prepared by polluting it with cadmium $\left(\mathrm{CdCl}_{2}\right)$, adding NPKMg fertilisers, and potentially alleviating substances (in proper subjects). After mixing the soil in a polyethylene pot, it was packed into pots $\left(3.5 \mathrm{dm}^{3}\right)$, in the amount of $3.2 \mathrm{~kg}$ per pot. Subsequently, the level of humidity was modulated to $60 \%$ of capillary water capacity in all objects. One level of fertilization with macro- and microelements was applied, which were converted to a pure component in $\mathrm{mg} \mathrm{kg}^{-1}$ of soil: $\mathrm{N}-$ $250\left[\mathrm{CO}\left(\mathrm{NH}_{2}\right)_{2}\right], \mathrm{P}-50\left(\mathrm{KH}_{2} \mathrm{PO}_{4}\right), \mathrm{K}-90\left(\mathrm{KH}_{2} \mathrm{PO}_{4}\right)$, $\mathrm{Mg}-20\left(\mathrm{MgSO}_{4} \cdot 7 \mathrm{H}_{2} \mathrm{O}\right), \mathrm{Cu}-5\left(\mathrm{CuSO}_{4} \cdot 5 \mathrm{H}_{2} \mathrm{O}\right), \mathrm{Zn}-$ $5\left(\mathrm{ZnCl}_{2}\right), \mathrm{Mo}-5\left(\mathrm{NaMoO}_{4} \cdot 2 \mathrm{H}_{2} \mathrm{O}\right), \mathrm{Mn}-5\left(\mathrm{MnCl}_{2}\right.$. $\left.4 \mathrm{H}_{2} \mathrm{O}\right)$ and $\mathrm{B}-0.33\left(\mathrm{H}_{3} \mathrm{BO}_{3}\right)$ were used in all experiments. Spring barley of the Rabel cultivar was then sown at certain sites. After sprouting, plants were segregated and 15 items were left per pot. The plant vegetation period was 50 days. The dry matter yield was determined after harvesting the spring barley $(\mathrm{BBCH}$ $52,20 \%$ of inflorescence emerged).

\subsection{Substances Used for Biostimulation}

Basalt meal (Stomeb PPHU, Mietków, Poland) and brown algae extract-Labimar 10S (P.U.H. "PolgerKido", Słupsk, Poland)—were experimentally applied to the soil in doses 0 and $5 \mathrm{~g} \mathrm{~kg}^{-1} \mathrm{DM}$ of soil (basalt meal) and 0 and $1.56 \mathrm{~cm}^{3} \mathrm{~kg}^{-1} \mathrm{DM}$ of soil (Labimar 10S), respectively. Basalt meal includes: $\mathrm{P}-1.7, \mathrm{~K}-10$, $\mathrm{Ca}-68.5, \mathrm{Mg}-40.9, \mathrm{Si}-231.4, \mathrm{Al}-84.7, \mathrm{Fe}-93.5$, $\mathrm{Na}-21.5, \mathrm{Mn}-1.5\left(\mathrm{~g} \mathrm{~kg}^{-1}\right)$ and trace amounts of $\mathrm{Zn}$, $\mathrm{Cu}, \mathrm{B}, \mathrm{Mo}, \mathrm{Co}$. The extract of brown algae included: dry matter (45\%), organic matter (36\% - amino acids, vitamins, mono-, poly- and oligosaccharides, enzymes, phytohormones) and organic boron (2.5\%). The content 
of elements for these substances was determined by producers. Finely ground barley straw was introduced in doses 0 and $5 \mathrm{~g} \mathrm{~kg}^{-1} \mathrm{DM}$ soil, as an alternative conventional method for the reclamation of soil. All substances were introduced into the soil. The impact of substances was determined based on the impact coefficient of an alleviating substance that was calculated with the following formula (Zaborowska et al. 2015):

$I F=\frac{\mathrm{Ss}}{\mathrm{Sc}}$

where:

IF coefficients of fertilization effect of an alleviating substance (IF $<1$ - an alleviating substance does not positively impact arylsulfatase activity or the number of Pseudomonas sp., IF $>1$ - an alleviating substance stimulates the analysed soil parameters),

Ss activity of arylsulfatase or the number of Pseudomonas sp. in soil with an alleviating substance,

Sc activity of arylsulfatase or the number of Pseudomonas sp. in soil without an alleviating substance.

2.3 Determination of the Activity of Soil Arylsulfatase and the Number of Pseudomonas sp.

The soil samples collected on day 25 and 50 of the experiment were tested for arylsulfatase activity (EC.3.1.6.1) with the method described by Alef and Nannipieri (1998). Potassium - 4 nitrophenylsulphate (PNS) was the substrate used to determine this enzyme. From each soil sample, $1 \mathrm{~g}$ of the soil, $4 \mathrm{~cm}^{3} 0.5 \mathrm{M}$ acetate buffer at $\mathrm{pH}=5.8$ and $1 \mathrm{~cm}^{3} 0.02 \mathrm{M}$ solution of PNS were added to it successively. The samples were incubated for $1 \mathrm{~h}$ at $37^{\circ} \mathrm{C}$. After the incubation, $25 \mathrm{~cm}^{3}$ distilled water was added to every sample. The content of each sample was then thoroughly mixed. After filtering, $4 \mathrm{~cm}^{3} 0.5 \mathrm{M} \mathrm{NaOH}$ was added to $6 \mathrm{~cm}^{3}$ of filtrate. This operation was repeated three times. Extinction of the produced 4 - nitrophenol was measured on an Aquarius CE7500 (Cecil Instruments) spectrophotometer, at a wavelength of $\lambda=420 \mathrm{~nm}$. The activity of arylsulfatase was expressed in micromoles PNP $\mathrm{kg}^{-1}$ DM of soil per hour. The soil samples were tested for the number of Pseudomonas sp. on a medium described by Wyszkowska et al. (2008). The number of microorganisms was determined with a colony counter. The recorded results are depicted as the rhizosphere effect (R:S), i.e. the ratio of arylsulfatase activity and number of Pseudomonas sp. in soil sown with spring barley $(\mathrm{R})$ to the same parameters in unsown soil (S). The activity of arylsulfatase and spring barley yielding were used to evaluate the resistance of soil (RS) to contamination with cadmium. Calculations were made with the formula proposed by Orwin and Wardle (2004).

$\mathrm{RS}=1-\frac{2|D 0|}{C 0+|D 0|}$

where: $D_{0}$ - the difference between control soil $\left(C_{0}\right)$ and contaminated soil after 25 days of incubation $\left(t_{0}\right)$. The control soil $\left(C_{0}\right)$ is not contaminated with cadmium and not biostimulated by any of the proposed substances. The values of RS remain in the range of 0 to 1 , where 1 indicates strong soil resistance, i.e. negligible effects of external factors. The lower the resistance, the stronger the impact of a given factor on the soil environment.

\subsection{Statistical Analysis}

The results were statistically processed using the STATISTICA v. 12.0 (Statsoft, Inc., Statistica 2016) statistical software package. Homogenous groups were calculated with Tukey's test at $P=0.01$. The coefficients of a simple Pearson correlation test of the increasing cadmium doses and the activity of arylsulfatase were determined. The rhizosphere effect after 25 and 50 days was illustrated using principal component analysis (PCA). The biostimulation Pseudomonas sp. counts on fertilizing substances was determined by cluster analysis and presented in a dendrogram in accordance with Ward's method. The percentage of variation of all investigated variables $\left(\eta^{2}\right)$ was determined with an analysis of variance (ANOVA). The following formula was used in this method:

$\eta^{2}=\frac{\mathrm{SS}_{\text {effect }}}{\mathrm{SS}_{\text {total }}} \cdot 100 \%$

where:

$\eta^{2} \quad$ coefficient $\eta^{2}$

$\mathrm{SS}_{\text {effect }}$ sum of squares for the analysed effect,

$\mathrm{SS}_{\text {total }}$ sum of squares for all effects. 


\section{Results and Discussion}

\subsection{Effect of Soil Contamination with Cadmium} on Arylsulfatase Activity

The results of these studies concerning the influence of $\mathrm{Cd}^{2+}$ on the biochemical activity of the soil correspond to the results obtained by other authors (Mikanova 2006; Zaborowska et al. 2015). Analysis of the $\eta 2$ coefficient proved that the dose used (24\%), the accumulation time of cadmium in the soil (14\%), and the soil use (8\%) significantly modified the activity of arylsulfatase. In the subjects sown with spring barley, doses in the range of 40-200 mg Cd $\mathrm{mg}^{2+} \mathrm{kg}^{-1} \mathrm{DM}$ of soil caused a stronger adverse influence on the activity of arylsulfatase than in the soil samples not used for cultivation (Fig. 1a, b). Knauff et al. (2003) observed the highest activity of arylsulfatase at a distance of $1 \mathrm{~mm}$ from the root.
However, Renella et al. (2006) noted an inhibition of the synthesis of citric acid, glutamic acid, oxalic acid and glucose in soil polluted with $20 \mathrm{mg} \mathrm{Cd}^{2+} \mathrm{kg}^{-1} \mathrm{DM}$ of soil. ${ }^{13} \mathrm{C}$ and ${ }^{14} \mathrm{C}$ studies showed very high initial rate of glucose mineralization $\left(1.1 \% \mathrm{~min}^{-1}\right)$ and much higher rate of sugars uptake by microorganisms from the soil solution (Gunina and Kuzyakov 2015). Researchers speculate that the most important functions of sugars in soil are to maintain and stimulate microbial activities in the rhizosphere leading to mobilization of nutrients by accelerated SOM decomposition. There is a strong correlation between microbial biomass-S and arylsulfatase activity (Vong et al. 2003). Therefore, cadmium pollution of soil already at dose of $40 \mathrm{mg} \mathrm{kg}^{-1} \mathrm{DM}$ of soil can causes strong stress reaction of microorganisms related to reduced availability of organic matter. It also indicates higher arylsulfatase activity in cadmium contaminated samples at doses of 0 and $4 \mathrm{mg} \mathrm{Cd} \mathrm{kg}-1$ DM of soil in
Fig. 1 Effect of soil contamination cadmium on arylsulfatase activity in the unsown (a) and sown soil (b), mM PNP kg ${ }^{-1}$ DM soil h

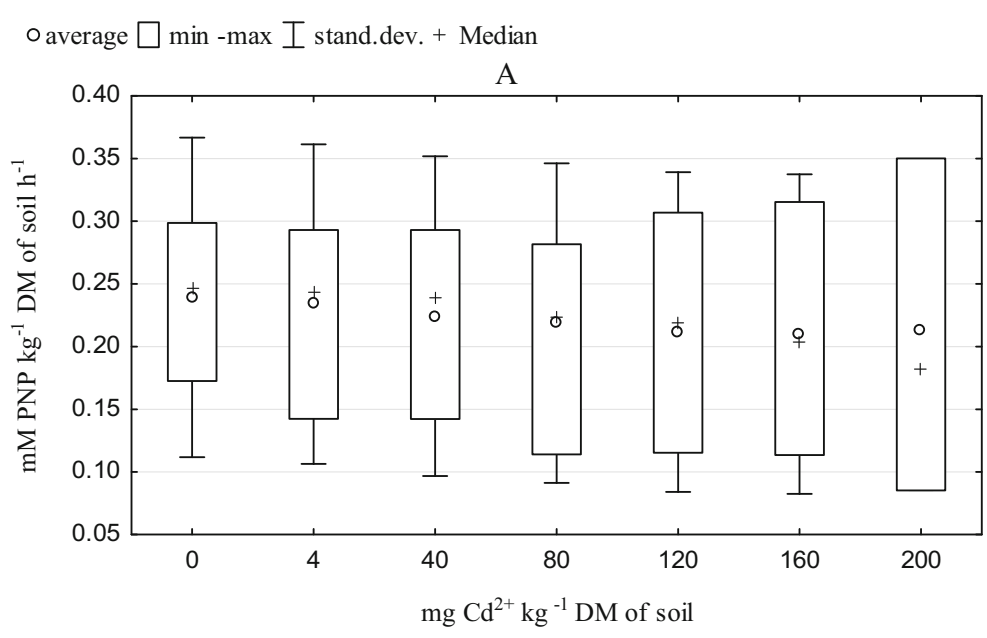

$\circ$ average $\square$ min-max $I$ stand dev. + Median

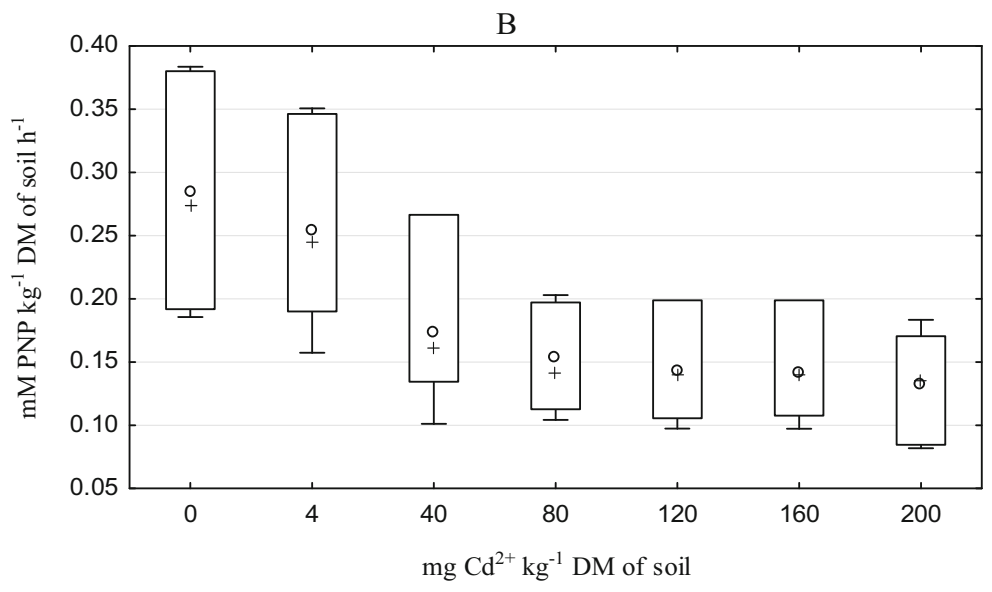


sown soil. Then, the strategy of their survival was induced, which caused their biodiversity to change. For example, for Microbacterium and Rhodococcus isolates, only a membrane arylsulfatase was found. The membrane arylsulfatase was induced both by substrate presence or S demand independently (Cregut et al. 2013). Potentially, the activity of these microorganisms could be inhibited.

The application of fertilizing substances did not give the expected effects in alleviating the results of $\mathrm{Cd}^{2+}$ inhibiting impact (Fig. 2). However, both in the pool of subjects sown and unsown with spring barley, a slight increase in the activity of arylsulfatase after the introduction of basalt meal and straw to the soil was observed. Brown algae extract did not meet the expectations of its potential.

The toxicity of $\mathrm{Cd}^{2+}$ for the individual enzymes, including arylsulfatase, was also proven by Mikanova (2006). This enzyme proved to be more sensitive to the tested metal than urease and invertase, and the adverse influence on its activity was observed after the application of just $2.4 \mathrm{mg} \mathrm{Cd}^{2+} \mathrm{kg}^{-1} \mathrm{DM}$ of soil. Dar (1996) observed an inverse dependence in the presence of $10 \mathrm{mg} \mathrm{Cd}^{2+} \mathrm{kg}^{-1} \mathrm{DM}$ of soil and the toxic properties of the tested metal became evident only with the dose of $50 \mathrm{mg} \mathrm{Cd}{ }^{2+} \mathrm{kg}^{-1} \mathrm{DM}$ of soil. The sensitivity of arylsulfatase to heavy metals close to that of other hydrolases, such as acid phosphatase and alkaline phosphatase, was also noted by Wyszkowska et al. (2010).

The use of indicators providing a chance for the complex analysis of the fertility of the soil under increasing pressure from $\mathrm{Cd}^{2+}$ contributed to an increase in the reliability of its stability evaluation. Most of all, however, it emphasised the interdependence between extending the accumulation time of this metal in the soil and its inhibiting power. The resistance (RS) of arylsulfatase was decreased from 36 to $50 \%$ (Table 2) compared to the samples with $4 \mathrm{mg} \mathrm{Cd}^{2+} \mathrm{kg}^{-1} \mathrm{DM}$ of soil, on the 25th and 50th incubation days, respectively.

The particular alleviating properties of basalt meal, which became evident after 50 days of incubation of the soil, and those of barley straw after 25 days of the experiment, are noteworthy. Basalt meal dissolves very slowly in nature, therefore, its stimulating effects are manifested after a long period of time (Shamshuddin et al. 2011). However, according (Shazana et al. 2013) under acid sulphate soil conditions $(\mathrm{pH}<3.5)$, basalt is expected to dissolve much faster.

This was also demonstrated by the formed groups with homogenous variances. In the soil samples sown with spring barley, comparable dependences were found. However, cadmium generated a lower resistance of arylsulfatase, both on the 25th and 50th days of the experiment. In this group of subjects, it decreased by 62 and $57 \%$, respectively, in relation to the samples with $4 \mathrm{mg} \mathrm{Cd}{ }^{2+} \mathrm{kg}^{-1} \mathrm{DM}$ of soil applied. However, it was observed that none of the mitigating substances was able to improve the biochemical properties of the soil to a degree enabling reaching of a state Table 2 of equilibrium after the stress connected with pollution of the soil with the tested metal (Table 2). However, both brown algae extract and straw improved the resistance of arylsulfatase in the presence of $4 \mathrm{mg} \mathrm{Cd}^{2+} \mathrm{kg}^{-1} \mathrm{DM}$ of soil, particularly effectively on the 50th day of the experiment. These substances increased the RS values by 158 and $106 \%$, respectively.
Fig. 2 The influence of fertilizing substances (IF) on arylsulfatase activity in the unsown $(\mathrm{B}, \mathrm{A}, \mathrm{S})$ and sown (B1, A1, $\mathrm{S} 1)$ soil; $B$ basalt meal, $A$ algae, $S$ barley straw

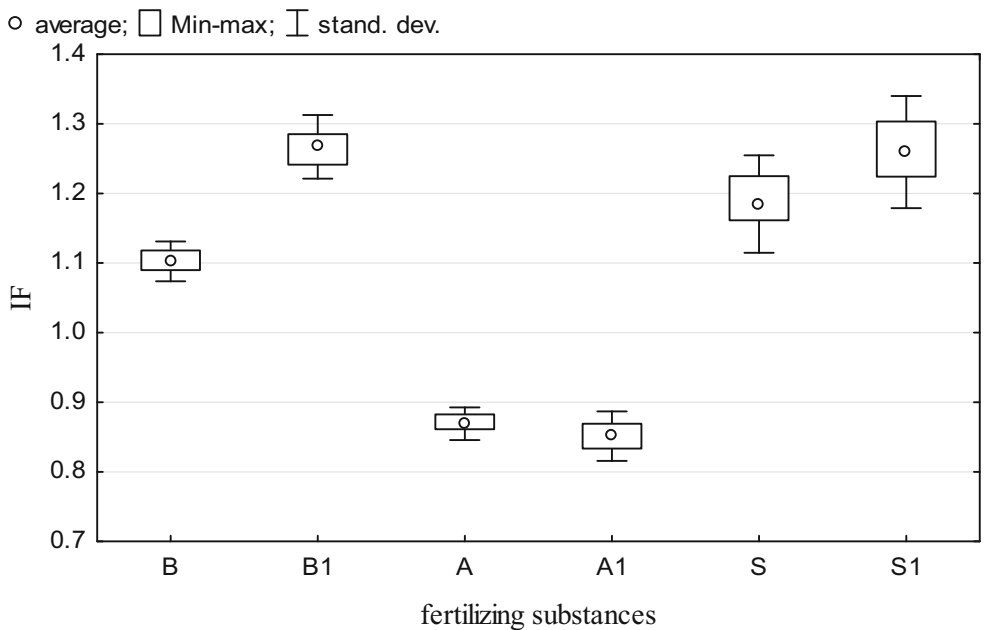


Table 2 Indicators of arylsulfatase resistance (RS) to soil contamination with $\mathrm{Cd}^{2+}$, subject to the applied soil fertilizing substances after 25 and 50 days

\begin{tabular}{|c|c|c|c|c|c|c|c|c|}
\hline \multirow{2}{*}{$\begin{array}{l}\text { Dose } \mathrm{Cd} \\
\left(\mathrm{mg} \mathrm{kg}^{-1} \mathrm{DM} \text { of soil) }\right.\end{array}$} & \multicolumn{2}{|l|}{ Control } & \multicolumn{2}{|c|}{ Basalt meal } & \multicolumn{2}{|l|}{ Algae } & \multicolumn{2}{|c|}{ Barley straw } \\
\hline & 25 & 50 & 25 & 50 & 25 & 50 & 25 & 50 \\
\hline \multicolumn{9}{|l|}{ Unsown } \\
\hline 4 & $0.876^{\mathrm{a}}$ & $0.856^{\mathrm{a}}$ & $0.750^{\mathrm{a}}$ & $0.865^{\mathrm{a}}$ & $0.887^{\mathrm{a}}$ & $0.271^{\mathrm{bcd}}$ & $0.910^{\mathrm{a}}$ & $0.466^{\mathrm{bc}}$ \\
\hline 40 & $0.778^{\mathrm{ab}}$ & $0.834^{\mathrm{a}}$ & $0.597^{\mathrm{ab}}$ & $0.933^{\mathrm{a}}$ & $0.700^{\mathrm{abc}}$ & $0.283^{\mathrm{bc}}$ & $0.798^{\mathrm{ab}}$ & $0.557^{\mathrm{abc}}$ \\
\hline 80 & $0.725^{\mathrm{ab}}$ & $0.768^{\mathrm{a}}$ & $0.431^{b c}$ & $0.881^{\mathrm{a}}$ & $0.633^{\mathrm{bcd}}$ & $0.225^{\mathrm{bcd}}$ & $0.794^{\mathrm{ab}}$ & $0.598^{\mathrm{abc}}$ \\
\hline 120 & $0.660^{\mathrm{abc}}$ & $0.750^{\mathrm{a}}$ & $0.344^{\mathrm{c}}$ & $0.864^{\mathrm{a}}$ & $0.501^{\mathrm{cde}}$ & $0.199^{\mathrm{bcd}}$ & $0.725^{\text {abc }}$ & $0.598^{\mathrm{abc}}$ \\
\hline 160 & $0.546^{\mathrm{bcd}}$ & $0.642^{\mathrm{ab}}$ & $0.344^{\mathrm{c}}$ & $0.747^{\mathrm{ab}}$ & $0.490^{\text {cdef }}$ & $0.131^{\mathrm{de}}$ & $0.637^{\mathrm{abc}}$ & $0.855^{\mathrm{a}}$ \\
\hline 200 & $0.558^{\mathrm{bcd}}$ & $0.429^{\text {bcd }}$ & $0.337^{\mathrm{c}}$ & $0.747^{\mathrm{ab}}$ & $0.382^{\mathrm{ef}}$ & $0.015^{\mathrm{e}}$ & $0.563^{\mathrm{bcd}}$ & $0.826^{\mathrm{ab}}$ \\
\hline Average & 0.691 & 0.713 & 0.468 & 0.839 & 0.599 & 0.187 & 0.738 & 0.643 \\
\hline$r$ & $-0.976^{*}$ & $-0.925^{*}$ & $-0.907 *$ & $-0.829 *$ & $-0.970 *$ & $-0.940^{*}$ & $-0.982 *$ & $0.935 *$ \\
\hline \multicolumn{9}{|l|}{ Sown } \\
\hline 4 & $0.909^{\mathrm{a}}$ & $0.591^{\mathrm{abc}}$ & $0.767^{\mathrm{a}}$ & $0.838^{\mathrm{a}}$ & $0.863^{\mathrm{ab}}$ & $0.629^{\mathrm{a}}$ & $0.879^{\mathrm{a}}$ & $0.963^{\mathrm{a}}$ \\
\hline 40 & $0.529^{\text {bcd }}$ & $0.374^{\mathrm{cd}}$ & $0.603^{\mathrm{ab}}$ & $0.483^{b c}$ & $0.421^{\mathrm{def}}$ & $0.558^{\mathrm{a}}$ & $0.509^{\text {cde }}$ & $0.574^{\mathrm{abc}}$ \\
\hline 80 & $0.529^{\mathrm{bcd}}$ & $0.266^{\mathrm{d}}$ & $0.582^{\mathrm{ab}}$ & $0.465^{\mathrm{cd}}$ & $0.287^{\mathrm{ef}}$ & $0.397^{\mathrm{ab}}$ & $0.300^{\mathrm{de}}$ & $0.317^{\mathrm{c}}$ \\
\hline 120 & $0.455^{\mathrm{cd}}$ & $0.250^{\mathrm{d}}$ & $0.542^{\mathrm{b}}$ & $0.369^{\mathrm{cd}}$ & $0.255^{\mathrm{ef}}$ & $0.359^{\mathrm{abc}}$ & $0.278^{\mathrm{e}}$ & $0.317^{\mathrm{c}}$ \\
\hline 160 & $0.418^{\mathrm{cd}}$ & $0.257^{\mathrm{d}}$ & $0.542^{\mathrm{b}}$ & $0.336^{\mathrm{d}}$ & $0.264^{\mathrm{ef}}$ & $0.372^{\mathrm{abc}}$ & $0.285^{\mathrm{e}}$ & $0.297^{\mathrm{c}}$ \\
\hline 200 & $0.347^{\mathrm{d}}$ & $0.250^{\mathrm{d}}$ & $0.502^{b c}$ & $0.336^{\mathrm{d}}$ & $0.243^{\mathrm{ef}}$ & $0.283^{\mathrm{abc}}$ & $0.281^{\mathrm{e}}$ & $0.270^{\mathrm{c}}$ \\
\hline Average & 0.531 & 0.313 & 0.590 & 0.471 & 0.389 & 0.425 & 0.422 & 0.421 \\
\hline$r$ & $-0.861^{*}$ & $-0.673^{*}$ & $-0.875^{*}$ & $-0.846^{*}$ & $-0.788^{*}$ & $-0.853^{*}$ & $-0.807 *$ & $-0.722 *$ \\
\hline
\end{tabular}

Same letters for a given fertilizing substances in columns are assigned to homogenous groups

$r$ correlation coefficient

*Significant for $P=0.01, n=17$

Undoubtedly, an excess of the retained cadmium in the soil leads to prolonged adverse effects for the biochemical properties of the soil. Lorenz et al. (2006) states that after 25 years, soil polluted with this metal in the amount of 50 and $250 \mathrm{mg} \mathrm{Cd}^{2+} \mathrm{kg}^{-1} \mathrm{DM}$ of soil still contained 34 and $134 \mathrm{mg} \mathrm{Cd}{ }^{2+} \mathrm{kg}^{-1} \mathrm{DM}$ of soil, respectively. An effective method for abatement of its toxic effect consists in using barley straw which, in studies by Wyszkowska et al. (2013), generated significantly higher values of resistance of the individual enzymes. The application of straw to soil has received great attention because of its potential benefits such as fertility improvement and carbon (C) sequestration. Straw amendment significantly increased respiration rate, total phospholipid fatty acids (PLFAs) and ${ }^{13} \mathrm{C}$ PLFA especially actinomycetes, Gram-positive bacteria and fungi (Pan et al. 2016). Microbial diversity and their populations are the important factors that govern the enzyme activities in soil. In turn, the enzyme activity in soil acts as the sensor of soil microbial and nutrient status and its fertility (Jain and Pandey 2016). However, the increasing $\mathrm{CO}_{2}$ emission as a result of its application cannot be omitted (Badía et al. 2013). One may also suppose that basalt meal will perform the expected alleviating role on the 50th day of the research because of a slow rate of dissolution under natural conditions (Shamshuddin et al. 2011). Its effectiveness is also supported by the release of $\mathrm{Ca}, \mathrm{Mg}, \mathrm{K}$ and $\mathrm{Na}$ cations in the form of both exchangeable and soluble cations. The magnitude of exchangeable cations, in order of decreasing content, was $\mathrm{Mg}>\mathrm{Ca}>\mathrm{K}>\mathrm{Na}$, while the order of soluble cations was $\mathrm{Na}>\mathrm{Mg}>\mathrm{Ca}>\mathrm{K}$ (Anda et al. 2015). What was surprising was the lack of significant biostimulation in the presence of brown algae. It should be emphasised that against the background of other algae, brown algae are characterised by exceptional sorptive properties for heavy metals (Romera et al. 2007). This is due to the occurrence of an alginate characterised by high affinity for biosorption in their cell wall. It should be stressed, however, that the process 
is stimulated by numerous factors: $\mathrm{pH}$, temperature, algae biomass, metal ion concentration and the presence of competitive ions (Zeraatkar et al. 2016).

\subsection{Effect of Soil Contamination with Cadmium on the Values of Rhizosphere Effect R:S}

The influence of the plant on the condition of soil subjected to pressure from $\mathrm{Cd}^{2+}$ was expressed as values of the rhizosphere effect R:S. This dependence was interpreted using the PCA method (Fig. 3).

On the 25th and 50th days of the research, the distribution of vectors around the axis representing the first factor described $68.22 \%$ of the total data variance. This means that the activity of arylsulfatase was positively correlated with this variable, irrespective of the time of $\mathrm{Cd}^{2+}$ accumulation in the soil. One homogeneous group formed, with positive values of vectors representing the primary component variables. The distribution of cases defined by both PCA axes corresponds to the influence of the used fertilizing substances on the values of the rhizosphere effect. The conducted analysis reflected a lack of any significant positive influence of the innovative substance applied to the soil. Only straw slightly abated the effects of $\mathrm{Cd}^{2+}$ inhibition, present in the dose of $40 \mathrm{mg} \mathrm{Cd}^{2+} \mathrm{kg}^{-1} \mathrm{DM}$ of soil. Both on the $25 \mathrm{th}$ and 50th days of the research, a comparable efficiency of the applied substances was observed.

The higher biological activity within the rhizosphere zone is well-known and is attributed to the beneficial role of root secretions (Wyszkowska et al. 2009).
However, protons $\mathrm{H}^{+}$liberated from the roots may lead to a decrease in $\mathrm{pH}$, thus lowering the enzyme activity. A compensating function is then performed by the higher metabolic activity of the biomass of microorganisms (Knauff et al. 2003). This is confirmed by the results of the authors' own study (Fig. 4) in which the number of Pseudomonas sp. was significantly higher in objects sown with spring barley. In addition, the separate clusters formed by samples fertilized with straw and basalt meal in the cluster analysis by Ward's method emphasized their significant, beneficial effect on the R:S values for Pseudomonas sp. No stimulation was noted for samples with the addition of algae which formed, along with control samples, a group with homogeneous variances. It is the sowing of the soil with the test crop in combination with the fertilization with straw that had the most beneficial effect on the number of Pseudomonas sp. (Fig. 5). However, irrespective of the pool of analysed object, the strength of inhibition of the increasing doses of $\mathrm{Cd}^{2+}$ contributed to the inhibition of the microbial activity corresponding to arylsulfatase activity.

In a study carried out by Zaborowska et al. (2015), $\mathrm{Cd}^{2+}$ had a more adverse effect on the number of cellulolytic and copiotrophic bacteria than it had on the number of Pseudomonas sp. In turn, straw generated higher R:S values for Pseudomonas sp. than it did for cellulolytic bacteria. An interesting relationship was also discovered by Ayano et al. (2015), who proved that for Pseudomonas aeruginosa stain RB, high resistance to cadmium is associated with the biosynthesis of CdSe
Fig. 3 The rhizosphere effect (R:S) arylsulfatase activity (average values): in soil contaminated with $\mathrm{Cd}^{2+}$ after 25 and 50 days. Dose $\mathrm{Cd}^{2+}, \mathrm{mg} \mathrm{kg}^{-1}$ DM of soil: 0 (cases: 1, 8, 15, 22), $4(2,9,16,23), 40(3,10,17,24)$, $80(4,11,18,25), 120(5,12,19$, 26), 200 (7, 14, 21, 28), cases: $1-$ 7 - control, 8-14 with basalt meal, 15-21 with algae, 22-28 with barley straw

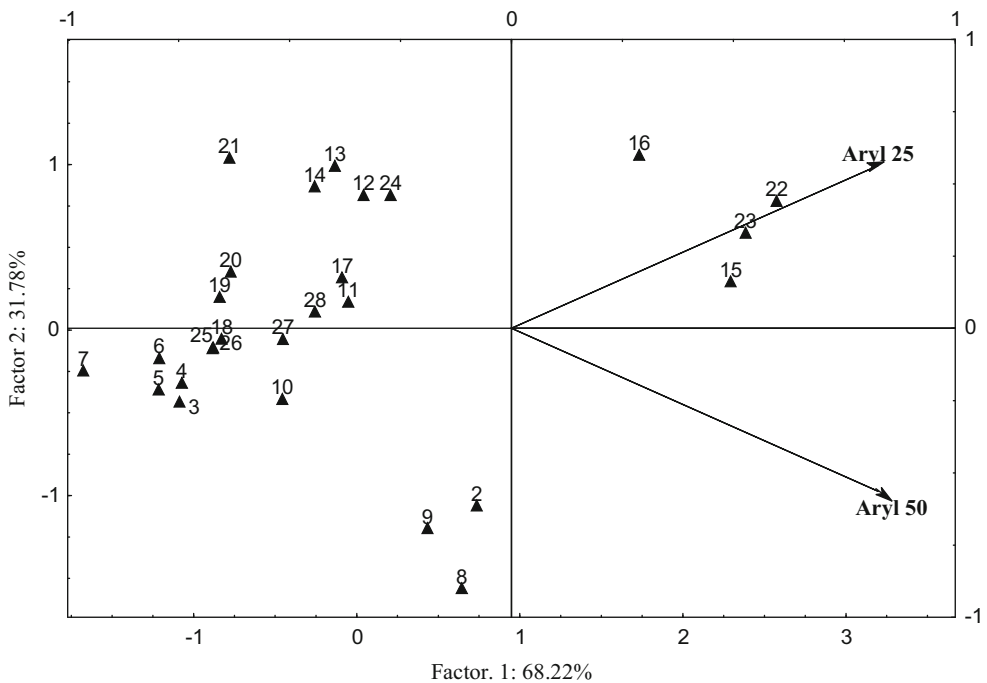


Fig. 4 The rhizosphere effect (R:S ratio) for Pseudomonas sp. counts in soil samples from control treatments exposed to biostimulation on fertilizing substances in soil contaminated with $\mathrm{Cd}^{2+}$. $C$ control, $B$ basalt meal, $A$ algae, $S$ barley straw
Ward's method, Euclidean dist.

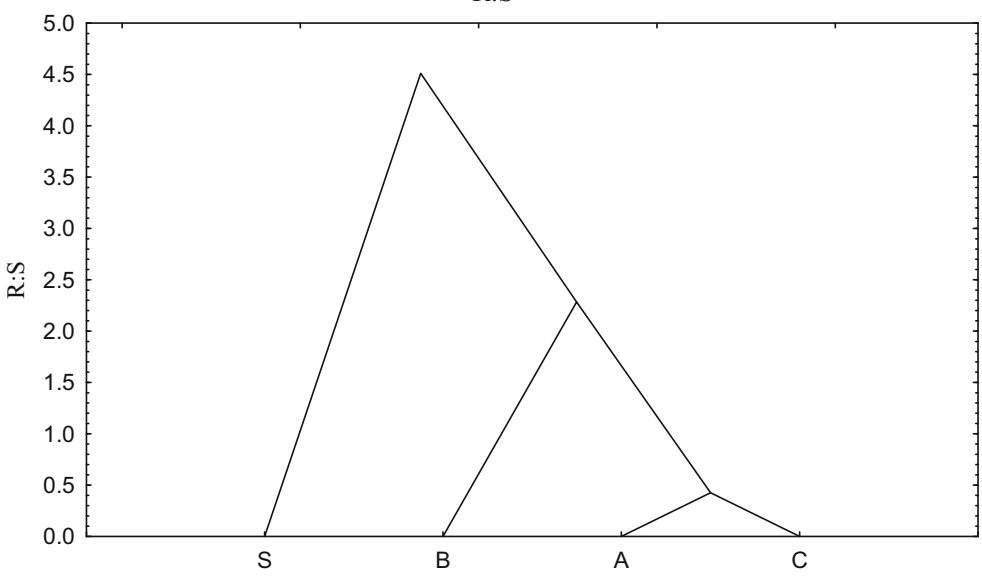

(cadmium selenide) by this microorganism in the presence of lactic acid as the carbon source. Furthermore, Kilic and Donmez (2008) emphasize that Pseudomonas sp. has a certain type of resistance to heavy metals, related to the mechanisms of biosorption or bioaccumulation of metals by an exopolysaccharide (EPS) produced by it. Undoubtedly, Pseudomonas sp., besides Actinobacteria, moderates arylsulfatase activity in the rhizosphere zone of spring barley (Cregut et al. 2009), and is also a significant microorganism for plants. Singh et al. (2013) emphasize the defensive function of the PHU094 strain of Pseudomonas aeruginosa in a plant's response to biotic stress by activating the induced systemic resistance (ISR) in the host. In turn, the symbiosis of plants with microorganisms as a phytoremediation factor, results in an improvement to the biological activity of soils (Wenhao et al. 2013).

Arylsulfatase has an indirect significant influence on crop quality. Thanks to its common occurrence in the soil, it contributes to making sulphur available to plants

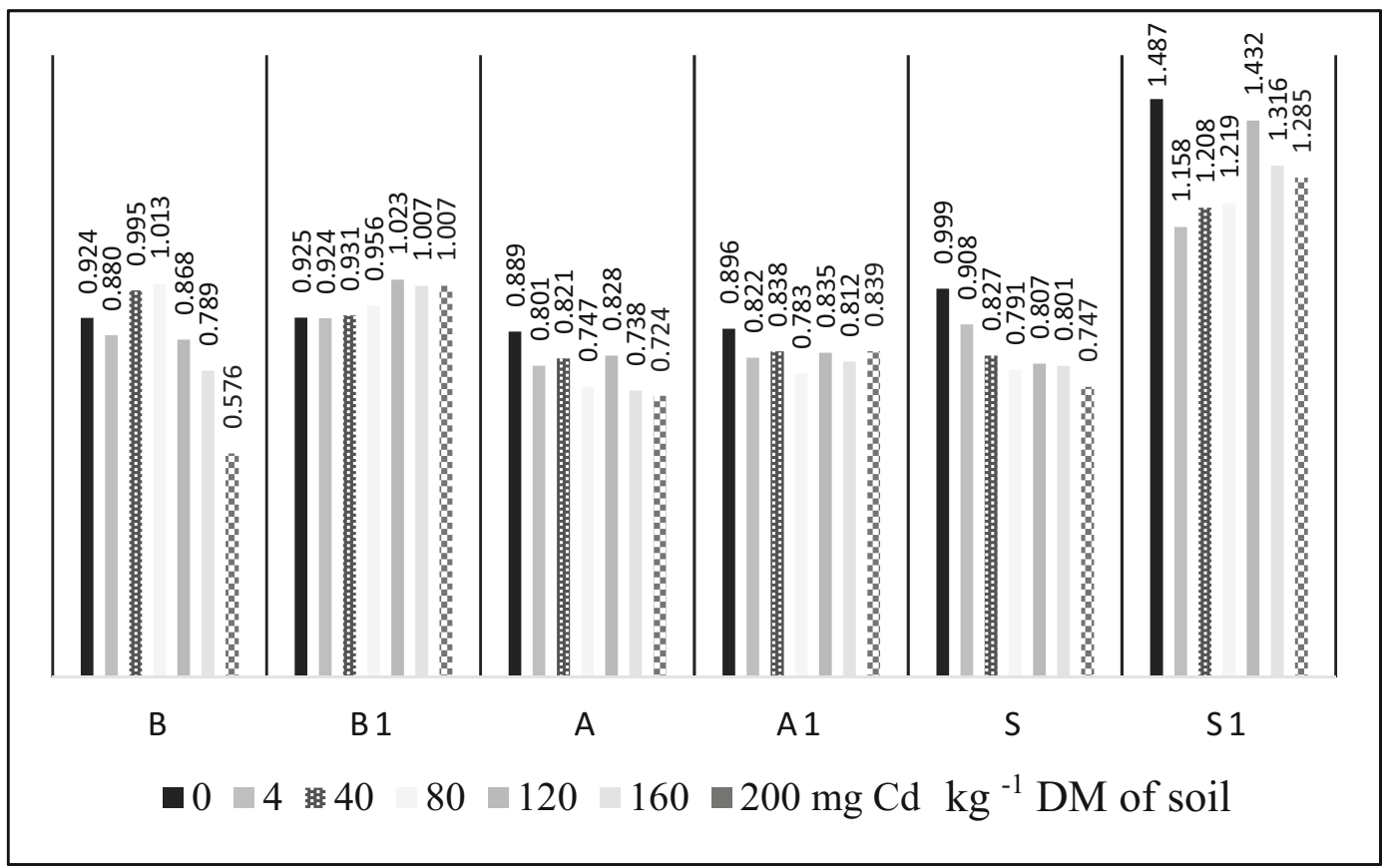

Fig. 5 The influence of fertilizing substances (IF) on the number of Pseudomonas sp. in the unsown (B, A, S) and sown (B1, A1, S1) soil contaminated with $\mathrm{Cd}^{2+} . B$ basalt meal, A algae, $S$ barley straw 
(Elsgaard and Vinther 2004). Slezack-Deschaumes et al. (2012) also suggest that microorganisms synthesize arylsulfatase at various stages of the plant's growth. The following Actinobacteria genera were identified: Arthrobacter, Oerskovia and Microbacterium, which are active at each stage of its development. In turn, Proteobacteria were associated with Pseudomonas, Klebsiella Raoultella and Sinorhizobium, and revealed their potential principally during the development of seeds. It should be stressed that approx. $41.5 \%$ of isolates were associated with Pseudomonas sp.

$\mathrm{Cd}^{2+}$ introduced to the soil also contributed to a decrease in the yield of the cultivated plant (Fig. 6). Inhibition of growth, chlorosis of leaves and deformation of the root system are some of the observed symptoms of the disturbance of biological mechanisms of spring barley as a result of stress connected with the application of the tested metal to the soil. However, this plant proved to be quite resistant to increasing pollution with $\mathrm{Cd}^{2+}$, particularly in doses above $80 \mathrm{mg} \mathrm{Cd}^{2+} \mathrm{kg}^{-1}$ DM of soil.

With monocotyledonous plants, deficiencies of this element do not become as visually evident as the consequence of excessive $\mathrm{Cd}^{2+}$ concentration in the soil. In studies by Wyszkowski and Wyszkowska (2009), the application of $60 \mathrm{mg} \mathrm{Cd}^{2+} \mathrm{kg}^{-1} \mathrm{DM}$ of soil reduced the spring barley crop by half, as a result of photosynthesis disturbance by $\mathrm{Cd}^{2+}$, according to Mohamed et al. (2012). The most favourable influence on the resistance of spring barley was exerted by straw. In the group of applied alleviating substances, the effectiveness of algae causes a great deal of controversy. However, the

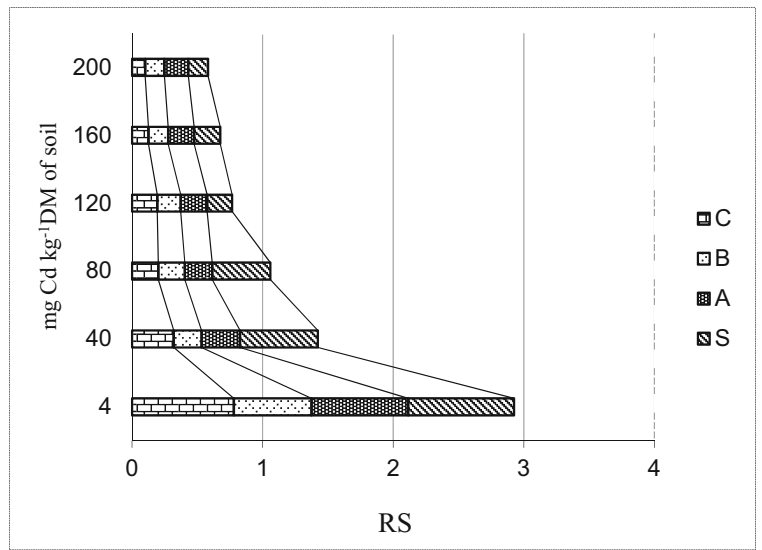

Fig. 6 Index of resistance (RS) of spring barley depending on cadmium pollution. $C$ control, $B$ basalt meal, $A$ algae, $S$ barley straw reaction of soil is a significant moderator of their activity. According to Yoshida et al. (2006), brown algae may become attractive biosorbents in the medium with $\mathrm{pH}>8$ or $\mathrm{pH}<5$. In addition, the process of metal ion biosorption is complex and usually takes place in two phases. The first phase is independent of the cell metabolism, while the second phase is based on the transport of ions to the cell's vacuole involving metallothionein (MTs) binding proteins (Monteiro et al. 2012). It is noteworthy that the identification of the significance of specific algae strains responsible for the kinetics and the mechanism of biosorption on the surface of their cells (Lee et al. 2016). Chlamydomunas reinhardtii has the capacity to rapidly adsorb $\mathrm{Cd}^{2+}$ ions and reaches equilibrium for the biosorption within $60 \mathrm{~min}$ (Mata et al. 2009). The defensive response of algae cells to metal ions is largely dependent on their resistance to oxidative damage. The excessive toxicity of $\mathrm{Cd}^{2+}$ to algae is reflected by the denaturation of protein structures, total chlorophyll loss, a reduced number of chloroplasts and the inhibition of cell growth (Lamaia et al. 2005). Opinions on the effect of temperature on biosorption vary. Khan et al. (2012) believe that the process is stimulated by its growth, while Gupta et al. (2010) observed that the heavy metal ion capture capacity increased with the decrease in the temperature. According to Aksu (2002), the maximum biosorption of $\mathrm{Cd}^{2+}$ by the algae occurred at 20 and $45{ }^{\circ} \mathrm{C}$. Basalt meal did not have such a beneficial effect on the yield of barley as straw had. This may be associated with an observation by Anda et al. (2013) that a short-term phenomenon formation of silicic acid $\left(\mathrm{H}_{4} \mathrm{SiO}_{4}\right)$ from basalt, which is adverse (from the perspective of microorganism functioning) may occur. This is, however, a short-term process, and the increase in $\mathrm{pH}$ value of the soil fertilized with basalt meal is attributed to the increase in exchangeable alkaline cations in soil (Anda et al. 2015; Nunes et al. 2014). In addition, in the presence of basalt meal, the content of toxic Al and Mn decreases (Anda et al. 2015). The positive effects of this were noted by Zuba et al. (2011), who demonstrated that the use of basalt significantly reduced the incidence of soft rot and pests compared to the use of chemicals.

\section{Conclusions}

Arylsulfatase is a sensitive indicator for the pollution of soil with $\mathrm{Cd}^{2+}$. Time was shown to be an important 
moderator of $\mathrm{Cd}^{2+}$ toxicity, which increases in time. An innovative method for the fertilization of soil did not play as important a role in the reclamation of polluted soil as straw did. The efficiency of the applied alleviating substances may be arranged as follows: barley straw $>$ basalt meal $>$ brown algae extract. Sowing spring barley improved the biochemical properties of the soil.

Open Access This article is distributed under the terms of the Creative Commons Attribution 4.0 International License (http:// creativecommons.org/licenses/by/4.0/), which permits unrestricted use, distribution, and reproduction in any medium, provided you give appropriate credit to the original author(s) and the source, provide a link to the Creative Commons license, and indicate if changes were made.

\section{References}

Abinandan, S., \& Shanthakumar, S. (2015). Challenges and opportunities in application of microalgae (Chlorophyta) for wastewater treatment: a review. Renew. Sustain. Energy Reviews, 52, 123-132.

Aksu, Z. (2002). Determination of the equilibrium, kinetic and thermodynamic parameters of the batch biosorption of nickel(II) ions onto Chlorella vulgaris. Process Biochemistry, 38(1), 89-99.

Alef, K., \& Nannipieri, P. (1998). Methods in applied soil microbiology and biochemistry (p. 576). London: Academic Press Harcourt Brace \& Company.

Anda, M., Shamshuddin, J., \& Fauziah, C. I. (2013). Increasing negative charge and nutrient contents of a highly weathered soil using basalt and rice husk to promote cocoa growth under field conditions. Soil \& Tillage Research, 132, 1-11.

Anda, M., Shamshuddin, J., \& Fauziah, C. I. (2015). Improving chemical properties of a highly weathered soil using finely ground basalt rocks. Catena, 124, 147-161.

ASTDR (2012). Agency for Toxic Substance and Disease Registry, U.S. Toxicological Profile for Cadmium. Department of Health and Humans Services, Public Health Service, Centers for Disease Control, Atlanta, Georgia, USA.

Ayano, H., Kuroda, M., Soda, S., \& Ike, M. (2015). Effects of culture conditions of Pseudomonas aeruginosa strain RB on the synthesis of CdSe nanoparticles. Journal of Bioscience and Bioengineering, 119(4), 440-445.

Badía, D., Marti, C. J., \& Aguirre, A. (2013). Straw management effects on $\mathrm{CO}_{2}$ efflux and $\mathrm{C}$ storage in different Mediterranean agricultural soils. Science of the Total Environment, 465, 233-239.

Berteau, O., Guillot, A., Benjdia, A., \& Rabot, S. (2006). A new type of bacterial sulfatase reveals a novel maturation pathway in prokaryotes. Journal of Biological Chemistry, 281(32), 22464-22470.

Byun, D. S., Kim, D. S., Godber, J. S., Nam, S. W., Oh, M. J., \& Shim, H. S. (2004). Isolation and characterization of marine bacterium producing arylsulfatase. Journal of Microbiology and Biotechnology, 14(6), 1134-1141.
Cregut, M., Piutti, S., Vong, P. C., Slezack-Deschaumes, S., Crovisier, I., \& Benizri, E. (2009). Density, structure, and diversity of the cultivable arylsulfatase-producing bacterial community in the rhizosphere of field grown rape and barley. Soil Biology and Biochemistry, 41(4), 704-710.

Cregut, M., Piutti, S., Slezack-Deschaumes, Z., \& Benizri, E. (2013). Density, structure and diversity of the cultivable arylsulfatase-producing bacterial community in the rhizosphere of field-grown rape and barley. Soil Biology \& Biochemistry, 168(1), 12-21.

Dar, G. H. (1996). Effects of cadmium and sewage-sludge on soil microbial biomass and enzyme activities. Bioresource Technology, 56, 141-145.

Elsgaard, L., \& Vinther, F. (2004). Modelling of the temperature response of arylsulfatase activity. Journal of Plant Nutrition and Soil Science, 167, 196-201.

EPA (2011). Pollutant limits. U.S. Environmental Protection Agency. Code of Federal Regulations 40 CFR 503.13 http://www.gpo.gov/fdsys/pkg/CFR-2011-title40-vol30/pdf/ CFR-2011-title40-vol30-part503.pdf. September 10, 2012.

Gil-Sotres, F., Trasar-Cepeda, C., Leiros, M. C., \& Seoane, S. (2005). Different approaches to evaluate soil quality using biochemical properties. Soil Biology and Biochemistry, 37, 877-887.

Gunina, A., \& Kuzyakov, Y. (2015). Sugars in soil and sweets for microorganisms: Review of origin, content, composition and fate. Soil Biology \& Biochemistry, 90, 87-100.

Gupta, V. K., Rastogi, A., \& Nayak, A. (2010). Biosorption of nickel onto treated alga (Oedogonium hatei): application of isotherm and kinetic models. Journal of Colloid and Interface Science, 342(2), 533-539.

Hao, F., Wang, X., \& Chen, J. (2006). Involvement of plasmamembrane NADPH oxidase in nickel-induced oxidative stress in roots of wheat seedlings. Plant Science, 170, 151158.

Houben, D., Evrard, L., \& Sonet, P. (2013). Mobility, bioavailability and $\mathrm{pH}$-dependent leaching of cadmium, zinc and lead in a contaminated soil amended with biochor. Chemosphere, 92, 1450-1457.

Jain, R., \& Pandey, A. (2016). Soil enzymes and microbial endophytes as indicators of climate variation along an altitudinal gradient with respect to wheat rhizosphere under mountain ecosystem. Rhizosphere, 2, 75-84.

Jezierska-Tyś, S., \& Frąc, M. (2006). Enzymatic activity of greybrown podzolic soil enriched with sewage sludge from a dairy plant. Polish Journal of Soil Science, 39(1), 33-42.

Kahnert, A., \& Kertesz, M. A. (2000). Characterization of a sulfurregulated oxygenative alkylsulfatase from Pseudomonas putida S-313. The Journal of Biological Chemistry, 275(41), 31661-31667.

Kertesz, M. A., Leisinger, T., \& Cook, A. M. (1993). Protein induced by sulfate limitation in Escherichia coli, Pseudomonas putida and Staphylococcus aureus. Journal of Bacteriology, 175, 1187-1190.

Khan, S., Cao, Q., Zheng, Y. M., Huang, Y. Z., \& Zhu, Y. Z. (2008). Heath risks of heavy metals in contaminated soil and ford crops irrigated with wastewater in Beijing, China. Environmental Pollution, 152, 686-692.

Khan, M. A., Ngabura, M., Choong, T. S., Masood, H., \& Chuah, L. A. (2012). Biosorption and desorption of nickel on oil 
cake: batch and column studies. Bioresource Technology, 103(1), 35-42.

Kilic, N. K., \& Donmez, G. (2008). Environmental conditions affecting exopolysaccharide production by Pseudomonas aeruginosa, Micrococcus sp., and Ochrobactrum sp. Journal of Hazardous Materials, 154, 1019-1024.

Klute, A. (1996). Methods of soil analysis. Madison: American Society of Agronomy, Agronomy Monograph 9.

Knauff, U., Schulz, M., \& Scherer, H. W. (2003). Arylsulfatase activity in the rhizosphere and roots of different crop species. European Journal of Agronomy, 19, 215-223.

Kucharski, J., Wieczorek, K., \& Wyszkowska, J. (2011). Changes in the enzymatic activity in sandy loam soil exposed to zinc pressure. Journal of Elementology, 16(4), 577-589.

Lamaia, C., Kruatrachuea, M., Pokethitiyooka, P., Upathamb, E. S., \& Soonthornsarathoola, V. (2005). Toxicity and accumulation of lead and cadmium in the filamentous green alga Cladophora fracta (OF Muller ex Vahl) Kutzing: a laboratory study. Science Asia, 31(2), 121-127.

Lee, H., Shim, E., Yun, H. S., Park, Y. T., Kim, D., Ji, M. K., et al. (2016). Biosorption of $\mathrm{Cu}(\mathrm{II})$ by immobilized microalgae using silica: kinetic, equilibrium, and thermodynamic study. Environmental Science and Pollution Research, 23(2), 10251034.

Longhua, W., Changyin, T., Ling, L., Ping, Z., Chang, P., Yongming, L., \& Christie, P. (2012). Cadmium bioavailability in surface soils receiving long-term applications of inorganic fertilizers and pig manure. Geoderma, 173-174, 224230.

Lorenz, N., Hintemann, T., Kramarewa, T., Katayama, A., Yasuta, T., Marschner, P., \& Kandeler, E. (2006). Response of microbial activity and microbial community composition in soil to long-term arsenic and cadmium exposure. Soil Biology and Biochemistry, 38, 1430-1143.

Macfarlane, G. R., \& Burchett, M. D. (2001). Photosynthetic pigments and peroxidase activity as indicators of heavy metal stress in the grey mangrove, Avicennia marina (Forsk.) Vierh. Marine Pollution Bulletin, 42, 233-240.

Mahmood, S., Malik, S. A., Tabassum, A., Younis, U., \& Athar, M. (2014). Biometric and biochemical attributes of alfalfa seedlings as indicators of stress induced by excessive cadmium. Journal of Soil Science and Plant Nutrition, 14(3), 546553.

Maksymiec, W., Wójcik, M., \& Krupa, Z. (2007). Variation in oxidative stress and photochemical activity in Arabidopsis thaliana leaves subjected to cadmium and excess copper in the presence or absence of jasmonate and ascorbate. Chemosphere, 66, 421-427.

Mata, Y. N., Blazquez, M. L., Ballester, A., Gonzalez, F., \& Munoz, J. A. (2009). Biosorption of cadmium, lead and copper with calcium alginate xerogels and immobilized Fucus vesiculosus. Journal of Hazardous Materials, 163(23), 555-562.

Mikanova, O. (2006). Effect of heavy metals on some soil biological parameters. Journal of Geochemical Exploration, 88, 220-223.

Mohamed, A. A., Castagna, A., Ranieri, A., \& Sanita di Toppi, L. (2012). Cadmium tolerance in Brassica juncea roots and shoots is affected by antioxidant status and phytochelatin biosynthesis. Plant Physiology and Biochemistry, 57, 15-22.
Monteiro, C., Castro, P. L., \& Malcata, F. X. (2010). Cadmium removal by two strains of Desmodesmus pleiomorphus cells. Water, Air \& Soil Pollution, 208(1-4), 17-27.

Monteiro, C. M., Castro, P. M. L., \& Malcata, F. X. (2012). Metal uptake by microalgae: underlying mechanisms and practical applications. Biotechnology Progress, 28(2), 299-311.

Munoz, R., Alvarez, M. T., Munoz, A., Terrazas, E., Guieysse, B., \& Mattiasson, B. (2006). Sequential removal of heavy metals ions and organic pollutants using an algal-bacterial consortium. Chemosphere, 63, 903-911.

Nelson, D. W., \& Sommers, L. E. (1996). Total carbon, organic carbon, and organic matter (in:) method of soil analysis: chemical methods, D.L. Sparks (Ed.), American Society of Agronomy, pp. 1201-1229, Madison, WI.

Nunes, J. M. G., Kautzmann, R. M., \& Oliveira, C. (2014). Evaluation of the natural fertilizing potential of basalt dust wastes from the mining district of Nova Prata (Brazil). Journal of Cleaner Production, 84, 649-656.

Oropeza-Garcia, N., Hausler, R., Glaus, M., Vega-Azamar, R., \& Romero-Lopez, R. (2014). Transport of heavy metals in materials with diameter analogous to xylem vessels. International Journal of Environmental Research, 8(1), $123-132$.

Orwin, K. H., \& Wardle, D. A. (2004). New indices for quantifying the resistance and resilience of soil biota to exogenous disturbances. Soil Biology and Biochemistry, 36, 1907-1912.

Pan, F., Li, Y., Chapman, S. J., \& Yao, H. (2016). Microbial utilization of rice straw and its derived biochar in a paddy soil. Science of the Total Environment, 559, 15-23.

Piutti, S., Slezack-Deschaumes, S., Niknahad-Gharmakher, H., Vong, P. C., Recous, S., \& Benizri, E. (2015). Relationships between the density and activity of microbial communities possessing arylsulfatase activity and soil sulfate dynamics during the decomposition of plant residues in soil. European Journal of Soil Biology, 70, 88-96.

Rao, M. A., Scelza, R., Scotti, R., \& Gianfreda, L. (2010). Role of enzymes in the remediation of polluted environments. Journal of Soil Science and Plant Nutrition, 10(3), 333-353.

Renella, G., Egamberiyeva, D., Landi, L., Mench, M., \& Nanipieri, P. (2006). Microbial activity and hydrolase activities during decomposition of root exudates released by an artificial root surface in Cd-contaminated soils. Soil Biology and Biochemistry, 38, 702-708.

Romera, E., Gonzalez, F., Ballester, A., Blazquez, M. L., \& Munoz, J. A. (2007). Comparative study of biosorption of heavy metals using different types of algae. Bioresource Technology, 98(17), 3344-3353.

Shamshuddin, J., Anda, N., Fauziah, C. I., \& Omar Syed, S. R. (2011). Growth of cocoa planted on highly weathered soil as affected by application of basalt and/or compost. Communications in Soil Science and Plant Analysis, 42(22), 2751-2766.

Shazana, M. R. S., Shamshuddin, J., Fauziah, C. I., \& Syed Omar, S. R. (2013). Alleviating the infertility of an acid sulphate soil by using ground basalt with or without lime and organic fertilizer under submerged condition. Land Degradation and Development, 24, 129-140.

Singh, A., Sarmab, B. K., Sanmukh, R., \& Singh, U. H. B. (2013). Compatible rhizosphere microbes mediated alleviation of biotic stress in chickpea through enhanced antioxidant and 
phenylpropanoid activities. Microbiological Research, 168, 33-40.

Slezack-Deschaumes, S., Piutti, S., Vong, P. C., \& Benizri, E. (2012). Dynamics of cultivable arylsulfatase-producing bacterial and fungal communities along the phenology of fieldgrown rape. European Journal of Soil Biology, 48, 66-72.

Smith, S. R. (2009). A critical review of the bioavailability and impacts of heavy metals in municipal solid waste composts compared to sewage sludge. Environment International, 35, 142-156.

Statsoft, Inc., Statistica (2016). Data analysis software system, version 12.0. www.statsoft.com.

Vong, P. C. H., Dedourge, O., Lasserre-Joulin, F., \& Guckert, A. (2003). Immobilized-S, microbial biomass-S and soil arylsulfatase activity in the rhizosphere soil of rape and barley as affected by labile substrate $\mathrm{C}$ and $\mathrm{N}$ additions. Soil Biology \& Biochemistry, 35(12), 1651-1661.

Vong, P. C., Piutti, S., Slezack-Deschaumes, S., Benizri, E., \& Guckert, A. (2010). Effects of low-molecular weight organic compounds on sulphur immobilization and remineralization and extraction of immobilized sulphur by hot-water and acid hydrolysis. European Journal of Soil Science, 61(2), 287297.

Wenhao, Y., Hong, H., Mei, R., \& Wuzhong, N. (2013). Changes of microbial properties in (near) rhizosphere soils after phytoextraction by Sedum alfredii $\mathrm{H}$ : a rhizobox approach with an artificial Cd-contaminated soil. Applied Soil Ecology, $72,14-21$.

Wyszkowska, J., Kucharski, J., \& Kucharski, M. (2008). Microbiological and biochemical properties of soil depending on adenine and azotobacterin applied. Journal of Elementology, 13(1), 127-138.

Wyszkowska, J., Kucharski, M., Kucharski, J., \& Borowik, A. (2009). Activity of dehydrogenases, catalase and urease in copper polluted soil. Journal of Elementology, 14(3), 605617.

Wyszkowska, J., Kucharski, M., \& Kucharski, J. (2010). Activity of $\beta$-glucosidase, arylsulfatase and phosphatases in soil contaminated with copper. Journal of Elementology, 15(1), 213-226.

Wyszkowska, J., Borowik, A., Kucharski, J., Baćmaga, M., Tomkiel, M., \& Boros-Lajszner, E. (2013). The effect of organic fertilizers on the biochemical properties of soil contaminated with zinc. Plant, Soil and Environment, 59(11), 500-504.

Wyszkowski, M., \& Wyszkowska, J. (2009). The effect of soil contamination with cadmium on the growth and chemical composition of spring barley (Hordeum vulgare L.) and its relationship with the enzymatic activity of soil. Fresenius Environmental Bulletin, 18(7), 1046-1053.

Yoshida, N., Kieda, R., \& Okuno, T. (2006). Identification and characterization of heavy metal-resistant unicellular alga isolated from soil and its potential for phytoremediation. Bioresource Technology, 97, 1843-1849.

Zaborowska, M., Kucharski, J., \& Wyszkowska, J. (2015). Remediation of soil contaminated with cadmium. Journal of Elementology, 20(3), 769-784.

Zaborowska, M., Kucharski, J., \& Wyszkowska, J. (2016). Biological activity of soil contaminated with cobalt, tin, and molybdenum. Environmental Monitoring and Assessment, 188, 398-408.

Zeraatkar, A. K., Ahmadzadeh, H., Talebi, A. F., Moheimani, N. R., \& McHenry, M. P. (2016). Potential use of algae for heavy metal bioremediation, a critical review. Journal of Environmental Management, 181, 817-831.

Zhu, Y., Liu, H., Qiao, C., Li, L., Jiang, Z., Xiao, A., \& Ni, H. (2017). Characterization of an arylsulfatase from a mutant library of Pseudoalteromonas carrageenovora arylsulfatase. International Journal of Biological Macromolecules, 96, 370-376.

Zuba, S. N., Nogueira, W. C. L., Fernandes, L. A., Sampaio, R. A., \& Costa, C. A. (2011). Yield and nutrition of tomato using different nutrient sources. Horticultura Brasileira, 29, 50-56.

Zwikel, S., Lavee, H., \& Sarah, P. (2007). Temporal dynamics in arylsulfatase enzyme activity in various microenvironments along a climatic transect in Israel. Geoderma, 140, 30-41. 